\title{
Analysis of Labor Market for Business English Graduates in China
}

\author{
Yumei Zhu \\ Sichuan University of Arts and Science, Dazhou, China \\ Email: jvj2008ns@hotmail.com
}

How to cite this paper: Zhu, Y.M. (2020) Analysis of Labor Market for Business English Graduates in China. Open Access Library Journal, 7: e7064.

https://doi.org/10.4236/oalib.1107064

Received: December 7, 2020

Accepted: December 26, 2020

Published: December 29, 2020

Copyright $\odot 2020$ by author(s) and Open Access Library Inc.

This work is licensed under the Creative Commons Attribution International License (CC BY 4.0).

http://creativecommons.org/licenses/by/4.0/

\begin{abstract}
This paper aims to find out the job opportunities and employers' requirements for Business English graduates by using content analysis of recruitment advertisements listed in 3 popular Chinese job-hunting websites. Research results show that most job opportunities for Business English graduates are sales in non-public listed private firms located in China's coastal area, and industry specifications are manufacturing and retail. Results also reveal that employers do not prefer the "business" feature of the new disciplinary.
\end{abstract}

\section{Subject Areas \\ Sociology}

Keywords

Business English, Job Market, China

\section{Introduction}

ESP education in China started from the late 1970s, aimed at English for science and technology purposes to echo the national policy of "Four Modernizations." ESP since then boomed, particularly in polytechnic and technology colleges where English for Technology Purpose, English for Petroleum Purpose, English for Metallurgy, and English for Medical Purposes were widely required as a compulsory course during students' three or four-year study in tertiary education (Cai, 2016) [1]. However, ESP failed in the late 1990s due to student's low General English level and teacher's incompetence to deliver both good content and language at the same time (Cai, 2016) [1]. Until the middle of the 2000s, as globalization increasingly tightened the connection between the Chinese and the rest of the world, ESP's need, particularly the business and academic side, revived. Many Chinese scholars argue that the learning of general English should 
be accomplished during middle school, while in the tertiary level, learner' program and disciplines features in different fields should be identified to guide English teaching, and some local Ministry of Education (Shanghai for example) in recent years officially approved ESP and EAP replaced General English in higher education level (Cai, 2013) [2].

From this century on, ESP experienced another fast growth. The business English, the sub-branch of ESP enjoyed an unprecedented development since 2000. Unlike other areas of ESP, BE in China has been approved as a formalized new discipline in 2007 by the Ministry of Education (MOE, 2007) [3]. Its nature is cross-disciplinary (Wang, 2015) [4], aiming to cultivate talents in both English language and business knowledge to satisfy China's internationalization needs.

Until 2018, 359 colleges offer to BE undergraduate degrees nationwide, while the 44 Graduate Program and 3 Ph.D. Program are provided mainly in eastern or focal universities. In 2018, the National Curriculum for BE Program in Business English of China (BE Curriculum) was officially approved by the MOE, which standardized the program, objects, and graduate requirements (MOE, 2018) [5]. According to the BE curriculum, the English language accounts for $50 \%-60 \%$ of the program, while business-related subject covers $25 \%-35 \%$ of the program, including economics, management, international law, and global marketing. Besides, problem-solving skills in the real business world (mainly using English as the working language) are significantly emphasized (Wang \& Cui 2020) [6] to differentiate itself from English's linguistic and literature side. In nature, BE in China is ambitiously featured using English to learn and deal with business-related issues (Weng, 2014) [7]. By examining the recruitment advertisement on three major job-hunting websites in China, this paper aims to determine the overall job opportunities and employer's requirements for $\mathrm{BE}$ graduates. Besides, this study is pedagogically motivated to understand what is the most important in the English business syllabus? This paper firstly reviews the current literature on Business English development and previous empirical researches in China of BE graduates' job market; secondly, how the data coding process, as well as key findings, will be explained; finally, based on the current result and national curriculum, the gap between $\mathrm{BE}$ education and skill required conducted in the discussion section.

\section{Literature Review}

In the beginning, ESP is need-driven and is designed to specify the needs of the learner (Strevens 1988) [8]. Johns, in 1980 [9], firstly introduced the term "business English.” F. Bargiela-Chiappini (2007) defines the term as all about how people communicate using talk or writing in commercial organizations to get their work done, as social action in business contexts (Bargiela-Chiappini, Nickerson and Planken, 2007) [10]. International scholars often suggest that Business English is a sub-discipline of applied linguistics-a complex interdisciplinary filed for researching the use of language in business and verbal specifics of business communication (Danyushina, 2011) [11]. And the academic studies focus on 
business discourse, such as annual reports (Fuoli, 2018) [12], corporate websites (Liu \& Wu, 2015) [13], and business media (Koller, 2005) [14]. In terms of pedagogy, business teaching material (Chan, 2009) [15], MBA student's workplace writing skills (Lentz, 2013) [16], academic reading, and Email-communication skills are of vital concern. In China, besides the mentioned area, the theoretical discussion also focuses on the social needs of business English graduates. In the job market, a study conducted in a Shanghai university found that there are notable differences between the skills and conceptual knowledge required for market needs (Wang, Wand \& Zheng, 2014) [17]. In this empirical study, more than $50 \%$ of graduates surveyed believed real business world skills is critical in the job market, but the study didn't specify the skills employer required. $\mathrm{Hu}$ (2020) [18] surveyed undergraduates of 5 universities in Chongqing and found that Business English graduates have more job opportunities than other English majors because other than teaching and translating jobs, they could have choices in trade and logistics. In terms of location, they are likely to work in local inland cities (Chengdu and Chongqing). And the current BE curriculum satisfies the social needs very well. At the same time, Shi \& Cheng (2019) [19] examined 326 advertisements in 2017 relevant to BE students. Their findings indicate that employers require real business world problem-solving skills and cross-cultural communication extensively. In terms of language proficiency, English writing and speaking are highly valued. The research concludes that the current curriculum generally satisfies social needs, but productive English skills and real world business skills should be reinforced in future syllabus design. However, it didn't state clearly what kind of business skills employers expected or specify how different employer requires skills differently.

"Business" is featured in Business English, and to differentiate itself from other disciplinary of English, a specially designed teaching guide is published in 2020. The newly published Teaching Guide for Undergraduate Business English is under the framework of the National Standards of Teaching Quality for Undergraduate Foreign Language and Literature Majors. One aim of the guide is to nurture graduates who can communicate in English in a business context as well as understand the global business world as a whole. The guide classified the core skills into language skills and technical skills, which accounts for $38 \%$ and $17 \%$, respectively. All language courses are "business" featured, for example, business reading and business writing. While the guide suggested five areas of professional business courses which local universities shall compulsorily courses are "business" featured, for example, business reading and business writing. While the guide suggested five areas of professional business courses which local universities shall compulsorily choose at least two of them when designing their own curriculum (Wang, 2015) [4]. And the suggested business professional courses are as follow (Table 1): professional business courses are as follow:

However, there exists a large discrepancy between what is designed and what is practiced in university classrooms. A study conducted in Guangdong University of Foreign Studies found in the BE department found that $39.82 \%$ of the 
Table 1. Recommend business professional courses.

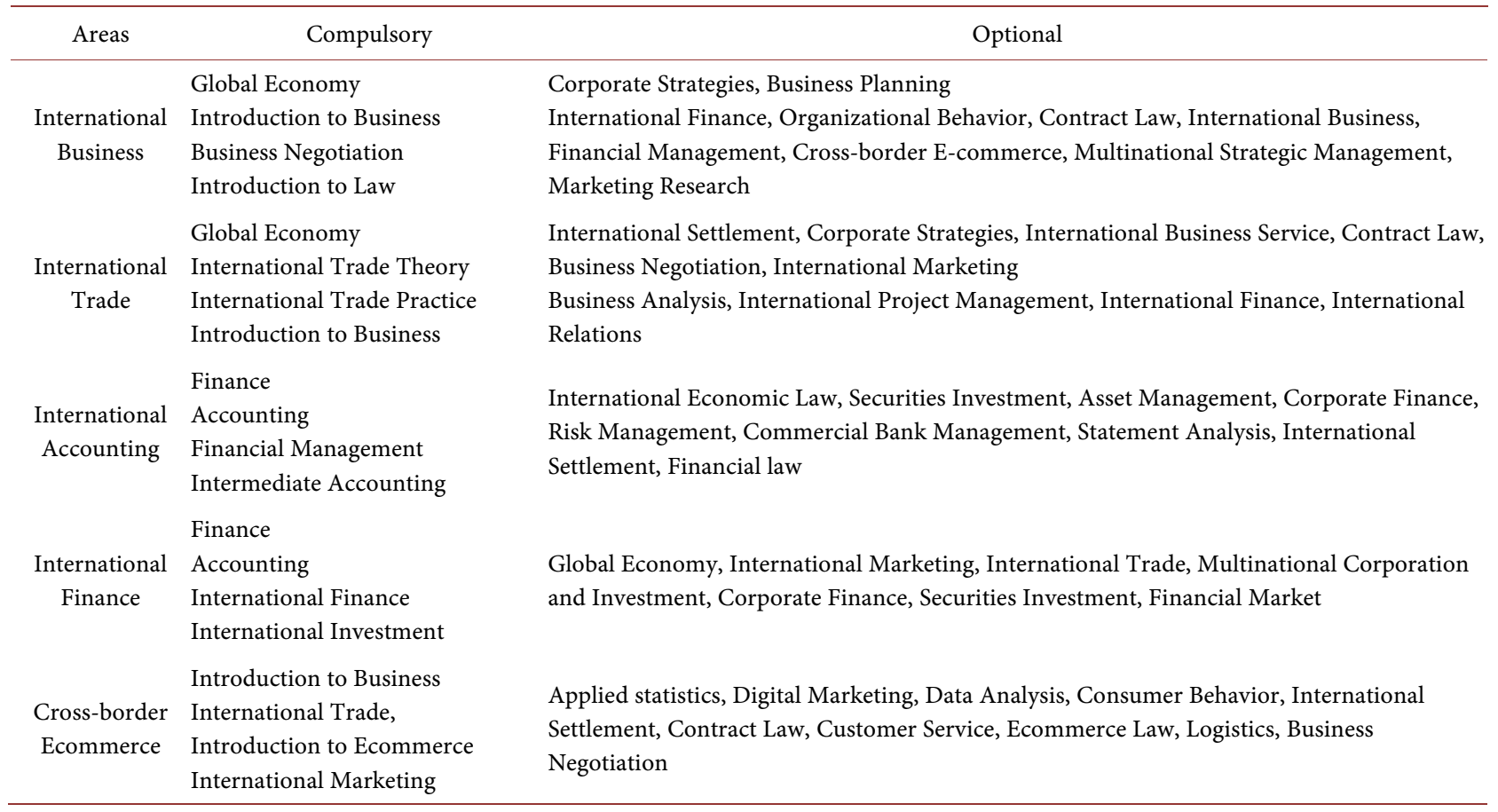

(Source from Teaching Guide for Undergraduate Business English Major.)

students mostly wanted to learn business knowledge in real workplaces, while learning English (31.86\%) accounted for the second important reason. Unfortunately, the research showed that $79.65 \%$ of the students feel the course is not career-oriented, and $42 \%$ of the students are dissatisfied with the teacher's level of business-related knowledge and skill. Another empirical study from $\mathrm{Li} \& \mathrm{Hu}$ based on 65 business English departments nationwide in 2017 found that teachers with business backgrounds (including business English) accounted for just $24 \%$ of the total, while most other teachers are English graduates.

\section{Research Questions and Method}

\subsection{Research Questions}

This research aims to answer the following four questions:

Research Question 1: What kinds of companies are interested in Business English graduates?

Research Question 2: Are the working opportunities featured any geographic preferences?

Research Question 3: What kind of business skills employers valued?

Research Question 4: What is the overall English proficiency requirement?

Research Question 5: Is there any gap between the employer's expectations and the BE graduate's skills?

\subsection{Research Method}

This study uses quantitative content analysis to examine job advertisements on 
three major domestic sites (51Job.com, Zhaopin.com, and ChinaHR.com). Content analysis is a research tool used to determine certain words, themes, or concepts within some given qualitative data (i.e., text). Using content analysis, researchers can quantify and analyze the presence, meanings, and relationships of certain words, themes, or concepts (Kääriäinen et al., 2014) [20]. The search function of the website was used to select the job listings used in this research. The search term "Business English" was used as the primary screen criterion. Geolocation preference is set for nationwide, and jobs that require or indicate a preference for the undergraduate degree was selected, while graduates degree and above and those required full-time experiences were skipped.

The sampling process began in October and lasted through November 2020, using job listing posted as early as $20^{\text {th }}$ of October, 2020. Generally, the recruitment demand at the beginning of the year will be more than that in the second half of the year. However, the unexpected pandemics in the beginning of this year impact the labor market, which destroys existing jobs and future job opportunities. Even though the research result might be influenced due to the smaller sample size compared with other years, it provides a breakdown of the job market for Business English graduates when the economy is recovering from a crisis.

All listings last for a month, and the listing was organized by date, so the most recent job postings appeared first. In total, 628 job listings were found in 51jobs.com, 657 in ChinaHR.com, and 925 in Zhaopin.com, duplicate listings were deleted, with 216 job listings left to quantitative content analysis. All data were categorized into business information, skill requirements, and salary. Business information includes types of corporations (public or non-public) and Metropolitan area, type of business (state-owned, private, and joint-venture), the industry of the company (Trade, logistic, technology, education, e-commerce, and manufacturing). Skill requirements include language proficiency and business skills. The salary section consists of the average salary and employee benefits (such as social securities, bonus, on-the-job training, and transport subsidy).

\section{Results and Findings}

Table 2 and Figure 1 summarize the type of business and industry. As Table 1 indicates, non-public listed private corporations make up the majority of the data $(80 \%)$, while public listed corporations account for just $6 \%$ of the total. In terms of the type of businesses, private companies account for the largest proportion of the data, joint ventures account for $14 \%$, while state-owned and foreign direct accounts for just $8 \%$. In terms of industries, Business English graduates may find job opportunities in different sectors, but most of them are in Retail and consumer goods (43\%), and manufacturing (29\%), followed by commercial services (12\%). In a word, this sample reflects those businesses and organizations that are interested in Business English graduates varied, but most job opportunities can be found in retail and consumer goods sectors, and the type of business is mostly private and non-public companies. 


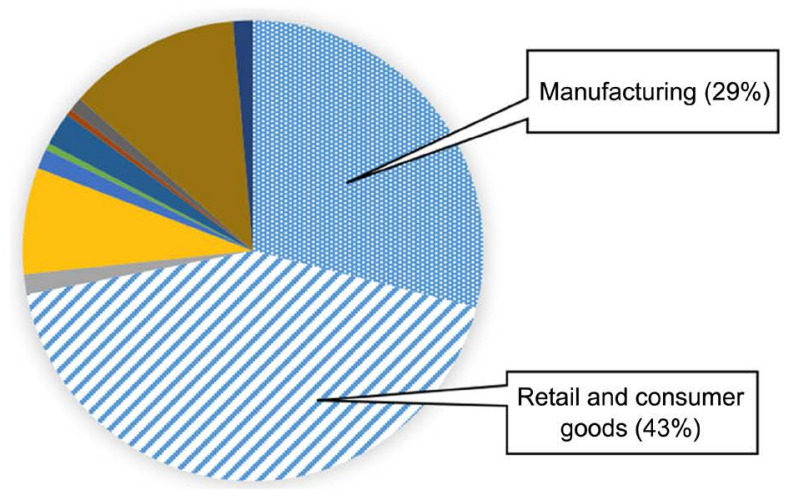

Figure 1. Type of industry.

Table 2. Type of businesses.

\begin{tabular}{cc}
\hline Types & Numbers \\
\hline State-owned & $8(4 \%)$ \\
Private(non-public listed) & $172(80 \%)$ \\
Private(public listed) & $13(6 \%)$ \\
Joint-venture & $14(6 \%)$ \\
FDI & $8(4 \%)$ \\
\hline
\end{tabular}

Job opportunities in different cities are classified into the following six regions. This metropolitan Region classification is consistent with the National Development and Reform Commission's plan (2015-2020) and almost covers all areas of China. From Table 3, most Business English job opportunities can be found in Jing-jin-jin, Yangtze Delta, and Pearl River Delta region; in total, it makes up $81 \%$, and all of them are coastal areas. The PRD and YRD were the firstly opened and reformed areas in China since 1978. It is the most populated, wealthiest, and dynamic region in China. In 2019, the two regions each contributed \$2 trillion of China's GDP growth, together with JJJ's \$2.4 trillion, the three region's total figure accounts for nearly half of last year's real GDP growth (source from 2019 National Bureau of Statistics). In other words, the economic dynamism in the region provide abundant employment opportunities, and business English graduates are more likely to find a job in this region than the other 3 .

Table 4 summarizes the language requirements listed in job announcements for Business English graduates. Language proficiency levels were classified into CET- 4 and above, CET- 6 and above, TEM- 4 and above, TEM- 8 and above, Fluent in English (this category refers to those companies who do not have certificate requirements but still require English fluency), and no requirements. CET is the abbreviation of National College English Teaching Syllabuses, and it consists of two levels of paper-based exam: CET-4, which is the lower level, and CET-6 
Table 3. Differences in the percentage of job listings by metropolitan region.

\begin{tabular}{cc}
\hline Area & Numbers \\
\hline Jing-Jin-Ji (JJJ) & $54(25 \%)$ \\
Yangtze River Delta (YRD) & $66(31 \%)$ \\
Pearl River Delta (PRD) & $54(25 \%)$ \\
Northeast & $3(1 \%)$ \\
Western China & $26(12 \%)$ \\
Central China & $12(6 \%)$ \\
\hline
\end{tabular}

Table 4. Language requirements.

\begin{tabular}{cc}
\hline Proficiency Level & Numbers \\
\hline CET-4 and above & $65(31 \%)$ \\
CET-6 and above & $63(29 \%)$ \\
TEM-4 & $4(2 \%)$ \\
TEM-8 & $4(2 \%)$ \\
Business English as the preference & $13(7 \%)$ \\
Fluent in English & $44(20 \%)$ \\
NO Requirements & $22(10 \%)$ \\
\hline
\end{tabular}

which is the higher level, and one speaking test (CET-SET) (Sourced from Syllabus for College English Test, 2006, p. 1) [21]. And CET test-taker is undergraduates in China who are majoring in any discipline. TEM is the abbreviation of National College English Teaching Syllabus for English Majors, a criterion that targeted university undergraduates majoring in English Language and Literature in China (NACFLT, 2004a [22], 2004b [23]). It consists of two levels of paper-based and speaking-based tests: TEM 4 and TEM 8, respectively. Overall, $90 \%$ of the employers require a certain level of fluency in English, and 63\% of them need graduates to prove their English level by officially approved certificates. However, it not hard to find out from Table 4 that most employers (59\%) recognize the CETs more than the TEMs, and only $7 \%$ of the total employers have a particular preference for Business English graduates.

Table 5 shows the top 5 occupational categories listed on the three websites. For Business English graduates, the largest proportion of market needs are sales; in total, there are 155 entries in the job list, which accounted for $72 \%$ of the sample, and the requirements can be found in all types of Business and industries. Classification of occupation is based on the "description of responsibilities." And for marketing jobs, the primary responsibility of the marketing job includes: managing the sales process, building relationships with key customers and vendors, advertising, mail campaigns, providing market feedback to the company leadership. Most of those tasks have to be done in English, as most of the marketing targets are international customers. Followed by secretary $8 \%$ and 
Table 5. Top 5 occupational categories.

\begin{tabular}{cc}
\hline Occupations & Numbers \\
\hline Marketing & $155(72 \%)$ \\
Secretary & $16(8 \%)$ \\
Website Maintenance & $11(5 \%)$ \\
Procurement & $8(4 \%)$ \\
Customer Service & $6(3 \%)$ \\
Strategic Planning & $6(3 \%)$ \\
\hline
\end{tabular}

website maintenance $5 \%$, all the other types of jobs are less than $4 \%$. Overall, when hiring fresh Business English graduates, employers emphasize market communication skills, maintaining and developing new customers, building relationships with existing and prospective customers and clients.

\section{Discussion}

The research results indicate that the type of business demand BE graduates are mostly private non-public listed companies. And when these companies do business or enter a foreign market, they need talents to communicate effectively in different kinds of business activities, such as bargaining, bidding, negotiation, and reporting. Also, talents with specialized skills and knowledge such as barristers who understand the home and foreign commercial laws could help a Chinese firm financing in Wall Street are demanded, enormously when the business expands internationally. However, the existing data shows that most Chinese firms outsource international financing or lawsuit case to local or international corresponding service providers. For example, when Alibaba went public on the New York Stock Exchange in 2014, International famous investment banks underwrote the shares, this includes Credit Suisse, Goldman Sachse, Morgan Stanley, JPMorgan, Deutsche Bank. Also, when it comes to commercial disputes between a Chinese and foreign company, dispute resolution often requires corporation between the Chinese, local, and even international lawyers. In other words, graduates with specialized knowledge in international law, accounting, and financing do have demands, but they are mostly hired by service sectors like investment banks and law firms. However, this study found that most working opportunities (72\%, Figure 1) can be found in the manufacturing and retail sector, in terms of commercial services, it just accounts for $12.9 \%$ of the total, and position in these sections are mostly sales, few are relevant to international accounting, financing, and laws. In other words, according to this research, BE graduates could have few chances of working in International accounting firms or investment banks. And it is sensible to question if professional courses like international accounting functional for BE graduates? And is the guide too ambitious?

Secondly, the study finds that marketing jobs are proportionally higher than other kinds, and this result is consistent with previous studies conducted na- 
tionwide (Shi \& Cheng, 2019) [19] and regional-focus ( $\mathrm{Hu}, 2020)$ [18]. In a word, Chinese employers value meta-skills like oral and written communication skills. In many previous studies, (Raymond, Carlson \& Hopkins, 2016) [24] found, business communication is essential not only for fresh entry-level graduates but also critical for a marketer's future career life. In some other places of the world, a study conducted in Australia found that oral communication skills were vital in the workplace for business graduate employees (Crosling and Ward, 2002) [25]. In developing countries, like Pakistan, communication and interpersonal skills are found as the most required skills for fresh graduates who are interested in marketing jobs (Saeed, 2015) [26]. It is notable that communication skills are often the topmost required skills for engineering (Ramadi et al., 2016) [27], hospitality (Yang et al., 2016) [28], accounting (Lim et al., 2016) [29], and real estate (Poon, 2012) [30]. In other words, questions and doubts may easily arise if the current nationwide business English teaching can satisfy the communication requirements or not. And if business technic skill courses still account for nearly half of the language courses, how could BE graduates guarantee their language proficiency level is as competent as other English majors? And finally, if BE graduates lose their advantages in communicative skills, how could they compete with professional marketing graduates?

Thirdly, English proficiency is a key for employability and advancement in the increasingly globalized world (Saeed, 2015) [26]. In this study, 90\% of the employers have requirements on language proficiency level; however, more than half of the requirements are CETs, only 7\% of the recruitment advertisement has English business preference. It is still unknown if the employers had any knowledge of the new discipline or not, or the employers intentionally extend the requirements so as to recruit the graduates they expected. But it can be confirmed from this study that English communicative competence is highly recognized by employers. And from their previous recruitment experiences, they believe that graduates with CET 4 and above are sufficient enough to deal with customers, clients, and any others. Business English is an important sub-disciplinary of ESP (Dudley-Evans \& St. John, 1998) [31], some scholar argues that General English and ESP differ not only like the learners, but also in the aim of instruction, However, in ESP, it is a needs analysis that determines which language skills are most needed by the learners, and the syllabus is designed accordingly (Rahman, 2016) [32]. However, any discipline of ESP is part of English language studies. Hutchinson and Waters (1987) [33] compare ESP to the leaves and branches on a tree of language; in this tree, roots and trunks are underlying language knowledge and support. But how could policymakers and curriculum designers convince the employers that $\mathrm{BE}$ graduates are more professionally competent than those majoring in marketing and English? And what kind of Business English syllabus makes the graduates more competitive in the globalized market?

\section{Conclusion}

This study examines job opportunities and the specific skills set and language 
proficiency level required for $\mathrm{BE}$ graduates that listed on three popular job-hunting websites in China. On the basis of quantitative data collected, the study shows that most job opportunities can be found in non-public listed private firms located in the most dynamic coastal area of China, and industry specifications are manufacturing and retail. As the world factory (Wang \& Li, 2017) [34], to promote the product or services, salesperson's communicative skills are highly needed to do business with international customers and clients (Schlee, Regina \& Harich, 2010) [35]. This study also proves that most working opportunities are sales jobs, and employers are expected strong marketing communicative skills. However, the current $\mathrm{BE}$ curriculum assigns nearly half of the core courses into technical skills like international accounting and financing. There could have concerns about how BE graduates' English communicative skills could satisfy the industry needs. In terms of English proficiency level, most employers believe English is critical for business' success. Still, only a few recruitment advertisements preferred graduates' fluency in Business English, even though a most sales job in the data requires business communication with International customers. It is still unknown that this dilemma is due to the employer's unawareness of the new disciplinary or their previous recruitment experience which graduates with CET qualifications with some on-the-job training are adequate to deal with customers. In this regard, BE curriculum designers and educators have to think profoundly about how BE graduates could be more competitive than other International business, marketing graduates? Or to make employers aware of the advantages of the new discipline.

\section{Fund Project}

This work was supported by SASU's Construction of Online Open Course: Economic and Trade Reading.

\section{Conflicts of Interest}

The author declares no conflicts of interest regarding the publication of this paper.

\section{References}

[1] Cai, J.G. (2016) ESP in China: Yesterday, Today and Tomorrow. Journal of University of Shanghai for Science and Technology, 2, 106-113.

[2] Cai, J.G. (2013) Some Comments on a Framework of Reference for EFL Teaching at Tertiary Level in Shanghai. Foreign Languages in China, 2, 2-10.

[3] Ministry of Education of the People's Republic of China (2007) Guidelines for Deepening the Reform of the College Undergraduate Programs and Enhancing the Quality of Instruction.

[4] Wang, L.F. (2015) Key Issues in Business English Program Development under the Guidance of the National Criterion of Teaching Quality for BA Program in Business. English Foreign Language Education in China, 8, 1-8.

[5] http://sfs.ahu.edu.cn/ upload/article/files/55/e1/a3a28bd64145933ecc3a893d614a/c 
23a894f-b3ed-4195-96ba-4bdb862d9cd4.pdf

[6] Wang, L.F. and Cui, C. (2020) Implementing the Teaching Guide for Undergraduate Business English Major and Improving Business English Talent Education. Foreign Language World, No. 3, 5-12.

[7] Weng, F.X. (2014) On the Dual-Track Development Mode of Business English. Foreign Language World, No. 2, 10-17.

[8] Strevens, P. (1988) The Learner and Teacher of ESP. In: Chamberlain, D. and Baumgardner, R., Eds., ESP in the Classroom: Practice and Evaluation, Modern English Publications in association with the British Council, London, 39-44.

[9] Johns, A. (1980) Cohesion in Written Business Discourse: Some Contrasts. The ESP Journal, 1, 35-44. https://doi.org/10.1016/0272-2380(80)90008-6

[10] Bargiela-Chiappini, F., Nickerson, C. and Planken, B. (2007) Business Discourse. Palgrave Macmillan, London. https://doi.org/10.1057/9780230627710

[11] Danyushina, Y. (2011) Business Linguistics: A New Interdisciplinary Synergy. International Journal of Arts and Sciences, 4, 177-186.

[12] Fuoli, M. (2018) Building a Trustworthy Corporate Identity: A Corpus-Based Analysis of Stance in Annual and Corporate Social Responsibility Reports. Applied Linguistics, 39, 846-885.https://doi.org/10.1093/applin/amw058

[13] Liu, M.and Wu, D. (2015) Discursive Construction of Corporate Identity on the Web: A Globalization Perspective. Intercultural Communication Studies, 24, 50-65.

[14] Koller, V. (2005) Critical Discourse Analysis and Social Cognition: Evidence from Business Media Discourse. Discourse and Society, 16, 199-224.

https://doi.org/10.1177/0957926505049621

[15] Chan, C.S.C. (2009) Forging a Link between Research and Pedagogy: A Holistic Framework for Evaluating Business English Materials. English for Specific Purposes, 28, 125-136. https://doi.org/10.1016/j.esp.2008.12.001

[16] Lentz, P. (2013) MBA Students' Workplace Writing: Implications for Business Writing Pedagogy and Workplace Practice. Business Communication Quarterly, 76, 474-490. https://doi.org/10.1177/1080569913507479

[17] Wang, Y.Y., Wang, G.L. and Zheng, L.N. (2014) Survey on the Needs and Cultivation Pattern of Business English Majors and Its Implications. Foreign Language World, No. 2, 85-90.

[18] Hu, J. (2020) Business Graduates Job Survey and Analysis of local University. Journal of Shengli College China University of Petroleum, No.1, 57-60.

[19] Shi, X.S. and Cheng, X. (2019) A Social Needs Analysis of Business English Talents. Foreign Language World, No. 2, 65-72.

[20] Elo, S., Kääriäinen, M., Kanste, O., Pölkki, T., Utriainen, K. and Kyngäs, H. (2014) Qualitative Content Analysis: A Focus on Trustworthiness. SAGE Open, 4, 1-10. https://doi.org/10.1177/2158244014522633

[21] Syllabus for College English Test (2006) National College English Testing Committee. Shanghai Language Education Press, Shanghai.

[22] NACFLT (2004) Syllabus for TEM4. Shanghai Foreign Language Education Press, Shanghai.

[23] NACFLT (2004) Syllabus for TEM8. Shanghai Foreign Language Education Press, Shanghai.

[24] Raymond, M.A., Carlson, L. and Hopkins, C.D. (2006) Do Perceptions of Hiring Criteria Differ for Sales Managers and Sales Representatives? Implications for Mar- 
keting Education. Journal of Marketing Education, 28, 43-55. https://doi.org/10.1177/0273475305284640

[25] Crosling, G. and Ward, I. (2002) Oral Communication: The Workplace Needs and Uses of Business Graduate Employees. English for Specific Purposes, 21, 41-57. https://doi.org/10.1016/S0889-4906(00)00031-4

[26] Saeed, K. (2015)Gaps in Marketing Competencies between Employers' Requirements and Graduates' Marketing Skills. Pakistan Business Review, 17, 125-146.

[27] Ramadi, E., Ramadi, S. and Nasr, K. (2016) Engineering Graduates' Skill Sets in the MENA Region: A Gap Analysis of Industry Expectations and Satisfaction. European Journal of Engineering Education, 41, 34-52.

https://doi.org/10.1080/03043797.2015.1012707

[28] Yang, H., Cheung, C. and Fang, C.C. (2015) An Empirical Study of Hospitality Employability Skills: Perceptions of Entry-Level Hotel Staff in China. Journal of Hospitality and Tourism Education, 27, 161-170. https://doi.org/10.1080/10963758.2015.1089510

[29] Lim, Y.-M., Lee, T.H., Yap, C.S. and Ling, C.C. (2016) Employability Skills, Personal Qualities, and Early Employment Problems of Entry-Level Auditors: Perspectives from Employers, Lecturers, Auditors, and Students. Journal of Education for Business, 91, 185-192.https://doi.org/10.1080/08832323.2016.1153998

[30] Poon, J. (2012) Real Estate Graduates' Employability Skills: The Perspective of Human Resource Managers of Surveying Firms. Property Management, 30, 416-434. https://doi.org/10.1108/02637471211273392

[31] Dudley-Evans, T. and St John, M.J. (1998) Developments in English for Specific Purposes. Cambridge University Press, Cambridge.

[32] Rahman, D. (2016) Making Malaysian Graduates More Employable a Reality. https://www.thestar.com.my/opinion/online-exclusive/whats-your-status/2016/07/1 4/making-malaysian-graduates-more-employable

[33] Hutchinson, T. and Waters, A. (1987) English for Specific Purposes. Cambridge University Press, Cambridge. https://doi.org/10.1017/CBO9780511733031

[34] Wang, B.J. and Li, X. (2017) From World Factory to World Investor: The New Way of China Integrating into the World. China Economic Journal, 10, 175-193. https://doi.org/10.1080/17538963.2017.1320047

[35] Schlee, R.P. and Harich, K.R. (2010) Knowledge and Skill Requirements for Marketing Jobs in the 21st Century. Journal of Marketing Education, 32, 341-352. https://doi.org/10.1177/0273475310380881 